\title{
PENERAPAN METODE DISCOVERY UNTUK MENINGKATKAN PRESTASI BELAJAR MATA PELAJARAN PROSES PENGOLAHAN DAN PENGAWETAN SISWA KELAS $X$ SMK NEGERI 2 PINRANG
}

\author{
Edi Abdullah 1), Husain Syam 2), Nurlaela Latief ${ }^{2)}$ \\ 1Alumni Program Studi Pendidikan Teknologi Pertanian \\ ${ }^{2}$ dan ${ }^{3}$ Dosen PTP FT UNM \\ putralapaleteang@yahoo.co.id
}

\begin{abstract}
This research is a class room action research that aims to improve the student learning achievements in processing and desiccation subject through particular discovery method at the 1st year class of SMK 2 Pinrang in 2014-2015 academic year, with 28 students. This study was conducted in two cycles, each cycle consists of planning, observation, and reflection stage. The treatment which has been done in first and second cycle was discovery method. The result showed that implementing of discovery method can improve student learning achievement. In the first cycle, the competence of student was $82,14 \%$ in average acquisition percentage and it has increased to $96.42 \%$ in the second cycle. The value acquisition in the second cycle was assumed completed according in KTSP (Curriculum Education Unit) $\geq 75$. Thus it can be said that the implementing of discovery method can improve academic achievement either in theory, practices and the way of learning
\end{abstract}

Keywords: Discovery Methods, Learning Achievement

\section{PENDAHULUAN}

Pendidikan kejuruan bertujuan
untuk meningkatkan kecerdasan,
kepribadian, akhlak mulia, serta
keterampilan peserta didik untuk hidup
mandiri, agar dapat bekerja secara
efektif dan efisien, mengembangkan
keahlian dan keterampilan, menguasai
bidang keahliannya, memiliki semangat
kerja yang tinggi, dan mampu
berkomunikasi sesuai dengan tututan
kerjanya. SMK Negeri 2 terletak di
Kelurahan Salo Kecamatan Watang
Sawitto Kabupaten Pinrang yang
merupakan salah satu lembaga

pendidikan kejuruan yang memiliki enam konsentrasi keahlian, salah satu konsentrasi di SMK Negeri 2 Pinrang adalah jurusan tekonologi pengolahan hasil pertanian atau disebut jurusan TPHP.

Mata pelajaran proses pengolahan dan pengawetan adalah salah satu mata pelajaran yang harus ditempuh oleh siswa sebelum melanjutkan ke mata pelajaran yang lain, baik secara teori maupun praktik. Praktik pengolahan dan pengawetan dalam istilah sekolah menengah kejuruan dimaksudkan sebagai latihan atau kegiatan yang dilakukan siswa dalam memperoleh 
keterampilan seperti mengolah, mengawetkan, dan mendistribusikan dalam dunia pemasaran. Siswa yang telah belajar teori atau praktik dan telah menguasai keterampilan dalam proses pengolahan dan pengawetan dapat dikategorikan telah memiliki kemampuan belajar pada fase psikomotorik. Namun pembelajaran proses pengolahan dan pengawetan siswa kelas X SMK Negeri 2 Pinrang selama ini masih menggunakan metode konvensional atau ceramah dan masih terpusat pada guru sehingga partisipasi siswa dalam kegiatan belajar kurang nampak dan tanggung jawab siswa masih kurang. Apabila guru menanyakan materi ataupun soal yang belum jelas, siswa terkesan malu-malu dan enggan untuk bertanya. Siswa tidak memiliki inisiatif maju ke depan tanpa ditunjuk sebelumnya oleh guru. Ketika ada salah satu siswa yang kurang tepat dalam mengerjakan soal di depan kelas, siswa lain kurang berani menyampaikan tanggapan atau ide yang berbeda dan hanya menunggu guru menjelaskan jawaban yang lebih tepat. Kenyataan tersebut berdampak pada prestasi belajar mata pelajaran proses pengolahan dan pengawetan siswa kelas $X$ SMK Negeri 2 Pinrang yang belum mencapai secara optimal. Metode pembelajaran yang diimplementasikan guru selama ini masih kurang mendukung peningkatan prestasi belajar siswa.

Prestasi belajar membutuhkan partisipasi dari berbagai pihak dan tidak hanya bergantung pada guru atau siswa itu sendiri, akan tetapi juga dipengaruhi oleh faktor keluarga. Perhatian orang tua sangat dibutuhkan oleh siswa demi motivasi belajar agar dapat mendapatkan prestasi yang baik. Hal tersebut akan dapat berjalan dengan baik jika terjadi keserasian antara motivasi belajar yang diberikan oleh orang tua ke anak dengan lengkap dan sarana prasarana yang memadai. Maka dari itu kedua hal ini harus diperhatikan oleh pelaksana pendidikan.

Menurut W.S. Winkel dalam Sunarto (2012) prestasi belajar merupakan bukti keberhasilan yang telah dicapai oleh seseorang. Hal ini berarti belajar merupakan hasil maksimum yang dicapai oleh seseorang setelah melaksanakan usaha-usaha belajar.

Menurut Arif Gunarso dalam Sunarto (2012) prestasi belajar adalah usaha maksimal yang dicapai oleh seseorang setelah melaksanakan usahausaha belajar. Prestasi dapat diukur melalui tes yang sering dikenal dengan tes prestasi belajar.

Berdasarkan data tes awal yang diperoleh pada Januari 2015 semester genap tahun ajaran 2014/2015, diketahui bahwa masih banyak siswa yang belum lulus pada mata pelajaran proses pengolahan dan pengawetan terkhusus pada kompetensi dasar mendemonstrasikan sampel dasar pengolahan dan pengawetan secara fisik karena nilainya belum mencapai standar kelulusan 75 sesuai diisyaratkan dalam kurikulum tingkat satuan pendidikan (Sumber: SMK Negeri 2 Pinrang). Dari 28 siswa, terdapat 12 siswa yang memperoleh nilai diatas 75 , ini berarti 
$42,86 \%$ yang lulus, sedangkan yang belum mencapai angka kelulusan terdapat 16 siswa atau $57,14 \%$ belum tuntas. Tuntutan sekolah terhadap keberhasilan siswa dalam kelas yaitu minimal $85 \%$ dan diupayakan $100 \%$, sedangkan persentase kelulusan siswa kelas $\mathrm{X}$ pada mata pelajaran proses pengolahan dan pengawetan terkhusus pada kompetensi dasar mendemonstrasikan sampel dasar pengolahan dan pengawetan secara fisik tahun ajaran 2014/2015 hanya 46,43\%, meski dalam kategori kurang namun kriteria tersebut belum mencukupi kriteria ketuntasan dari sekolah yakni minimal $85 \%$, ini berarti mata pelajaran tersebut yang dilaksanakan belum maksimal (laporan data sekunder tahun 2015). Dengan adanya berbagai kecenderungan situasi yang muncul seperti di atas, maka perlu ada penerapan metode pembelajaran yang diharapkan dapat meningkatkan prestasi belajar siswa.

Salah satu metode pembelajaran yang memungkinkan dapat meningkatkan prestasi belajar siswa adalah metode Discovery. Metode pembelajaran Discovery disebut juga metode pembelajaran penemuan dengan menekankan peran siswa akan belajar secara mandiri maupun berkelompok untuk membahas suatu masalah tertentu yang diberikan oleh guru. Disamping itu, siswa juga akan dituntut untuk berusaha mencari solusi sendiri terhadap apa yang di berikan oleh guru, baik secara teori maupun praktik. Proses pembelajaran harus dipandang sebagai suatu stimulus atau rangsangan yang dapat menantang siswa untuk merasa terlibat atau berpartisipasi dalam aktivitas pembelajaran. Peranan guru sebagai fasilitator dan pembimbing atau pemimpin pengajaran yang demokratis, sehingga diharapkan siswa lebih banyak melakukan kegiatan sendiri atau dalam bentuk kelompok memecahkan masalah atas bimbingan guru.

Menurut Djamarah et al. (2006) metode adalah suatu cara yang dipergunakan untuk mencapai tujuan yang telah ditetapkan. Dalam kegiatan belajar mengajar, metode diperlukan oleh guru dan penggunaannya bervariasi sesuai tujuan yang ingin dicapai setelah pembelajaran berakhir. Seorang guru tidak akan dapat melaksanakan tugasnya bila dia tidak menguasai satupun metode pembelajaran yang telah dirumuskan para ahli psikologi dan pendidikan.

Menurut Roestiyah (2001) Discovery Learning merupakan metode mengajar mempergunakan teknik penemuan. Metode discovery adalah proses mental dimana siswa mengasimilasi sesuatu konsep atau sesuatu prinsip proses mental tersebut misalnya mengamati, menggolongkan, membuat dugaan, menjelaskan, mengukur, membuat kesimpulan, dan sebagainya. Dalam teknik ini siswa dibiarkan menemukan sendiri atau mengalami proses mental itu sendiri, guru hanya membimbing dan memberikan instruksi.

Oleh karena itu, guru harus berusaha semaksimal mungkin untuk 
meningkatkan kompetensi dasar tersebut. Berdasarkan uraian di atas, mata pelajaran proses pengolahan dan pengawetan memerlukan adanya motivasi, inisiatif, rasa percaya diri, disiplin, dan tanggung jawab belajar dalam rangka meningkatkan prestasi belajar siswa, metode belajar yang digunakan juga harus dapat mendukung proses pembelajaran. Pada metode Discovery, diharapkan situasi belajar mengajar berpindah dari situasi teacher dominated learning menjadi situasi student dominated learning. Selain itu, penggunaan metode Discovery dalam mata pelajaran proses pengolahan dan pengawetan diharapkan akan menarik minat siswa mengikuti kegiatan belajar sehingga dapat meningkatkan prestasi belajar siswa.

Hal ini dipandang perlu untuk dilakukan penelitian tentang penerapan metode discovery untuk meningkatkan prestasi belajar siswa mata pelajaran proses pengolahan dan pengawetan siswa kelas X SMK Negeri 2 Pinrang. Penelitian ini bertujuan menerapkan metode discoveryuntuk meningkatan prestasi belajar mata pelajaran proses pegolahan dan pengawetan siswa kelas XSMK Negeri 2 Pinrang.

\section{METODOLOGI PENELITIAN}

Jenis penelitian yang digunakan adalah Penelitian Tindakan Kelas (PTK) yang dilakukan secara kolaboratif dan partisipatif.Penelitian ini dimaksudkan untuk memberikan informasi bagaimana cara untuk meningkatkan prestasi belajar oleh siswa dengan menggunakan metode discovery. Oleh sebab itu, penelitian ini difokuskan pada tindakantindakan sebagai usaha untuk meningkatkan prestasi dalam proses belajar dengan menggunakan metode discovery.

Desain dalam penelitian tindakan kelas ini peneliti menggunakan model Kemmis dan Mc. Taggart. Pelaksanaan penelitian tindakan meliputi empat langkah yaitu perencanaan (planning), pelaksanaan tindakan (action), pengamatan (observation), dan refleksi (reflection). Setiap langkah pelaksanaan termuat dalam suatu siklus. Siklus dihentikan jika penelitian yang dilakukan sesuai dengan rencana dan mengalami peningkatan.

Teknik pengumpulan data dilakukan dengan menggunakan instrument uji coba, lembar observasi setiap siklus, pre dan posttes dalam bentuk essay untuk mengetahui tingkat pemahaman dasar materi, serta dokumentasi berupa rekaman video dan foto agar data dalam pelaksanaan siklus lebih akurat .

Teknik analisis data yang digunakan dalam penelitian dianalisis secara kuantitantif. Analisis kuantitatif digunakan untuk mengelompokkan data hasil tes yang selanjutnya dikategorisasi untuk mengetahui tingkat keberhasilan siswa dalam menguasai kompetensi yang diajarkan, kemudian dihitung jumlah skor tiap-tiap butir pertanyaan sesuai dengan aspek-aspek yang diamati. Perhitungan persentase yang digunakan adalah sebagai berikut: 


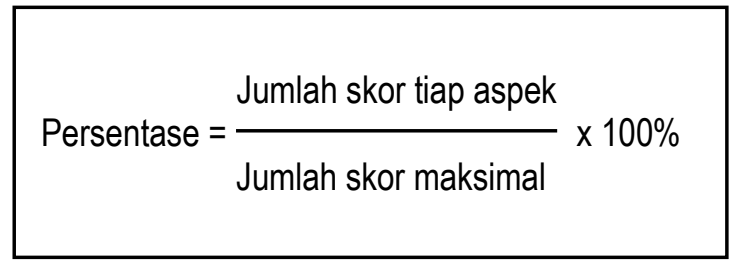

Dalam mengukur keberhasilan peserta belajar, digunakan teknik penilaian dari Departemen Pendidikan Nasional (Lestari, 2004).

\section{Tabel 1}

\section{Kualifikasi Hasil Persentase Skor}

\begin{tabular}{|l|l|}
\hline $\begin{array}{c}\text { Persentase skor } \\
\text { yang diperoleh }\end{array}$ & \multicolumn{1}{c|}{ Kategori } \\
\hline $85 \%-100 \%$ & Sangat baik \\
\hline $65 \%-84 \%$ & Baik \\
\hline $55 \%-64 \%$ & Cukup \\
\hline $35 \%-54 \%$ & Kurang \\
\hline $0 \%-39 \%$ & Sangat Kurang \\
\hline
\end{tabular}

Sumber : Departemen Pendidikan Nasional (Lestari, 2001)

\section{HASIL DAN PEMBAHASAN}

\section{A. Hasil Penelitian}

\section{Hasil Tes Awal}

Tes awal dilakukan sebagai pembanding sebelum menerapkan metode discovery, hasil tes awal pada pembelajaran proses pengolahan dan pengawetan ditulis dalam bentuk essay sebanyak 5 soal. Hasil disajikan pada Tabel 2.
Tabel 2

Data Distribusi Frekuensi Nilai Tes Awal

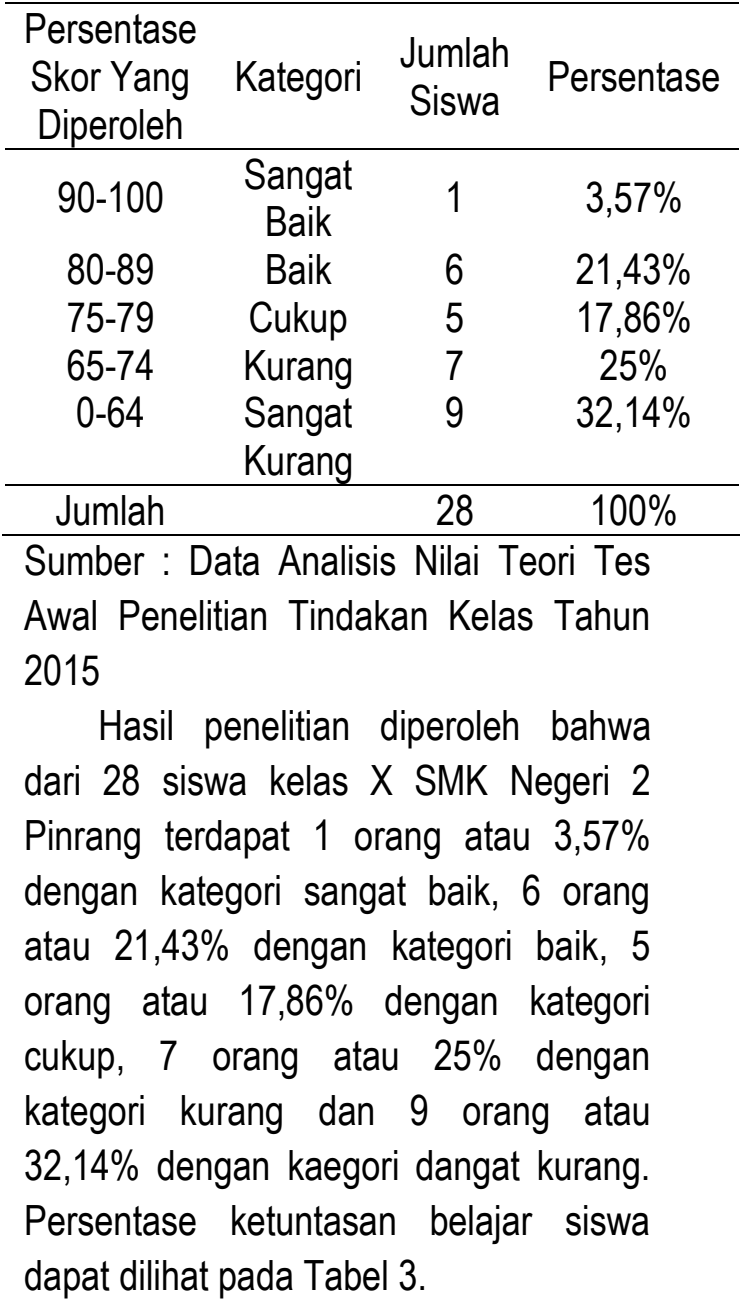

Tabel 3

Data Distribusi Frekuensi Ketuntasan Belajar Siswa pada Tes Awal

\begin{tabular}{cccc}
\hline Skor & $\begin{array}{c}\text { Frekuen } \\
\text { si }\end{array}$ & $\begin{array}{c}\text { Persentas } \\
\text { e }(\%)\end{array}$ & $\begin{array}{c}\text { Katego } \\
\text { ri }\end{array}$ \\
\hline $\begin{array}{c}100- \\
75\end{array}$ & 12 & $42,86 \%$ & Tuntas \\
$\begin{array}{c}74- \\
100\end{array}$ & 16 & $57,14 \%$ & $\begin{array}{c}\text { Tidak } \\
\text { Tuntas }\end{array}$ \\
\hline $\begin{array}{c}\text { Jumla } \\
\text { h }\end{array}$ & 28 & 100 & \\
\hline
\end{tabular}

Hasil distribusi frekuensi ketuntasan hasil belajar siswa pada tes awal 
diperoleh bahwa dari 28 siswa kelas $X$ SMK Negeri 2 Pinrang terdapat 12 orang atau $42,86 \%$ yang mencapai batas lulus atau sudah kompeten. Hasil juga memperlihatkan masih terdapat 15 siswa atau $57,14 \%$ yang belum mencapai batas kelulusan atau belum kompeten lulus berdasarkan kriteria ketuntasan minimal (KKM) dalam kurikulum satuan tingkat pendidikan (KTSP) serta tuntutan sekolah yakni minimal $85 \%$.

\section{Hasil Penelitian Siklus I}

\section{a. Hasil Tes Siklus I}

Setelah dilakukan pembelajaran proses pengolahan dan pengawetan dengan menggunakan metode discovery diperoleh hasil belajar siswa yang disajikan pada Tabel 4.

Hasil penelitian yang diperoleh menunjukkan bahwa dari 28 siswa kelas $X$ SMK Negeri 2 Pinrang terdapat 8 orang atau $28,58 \%$ dengan kategori sangat baik, 12 orang atau $42,86 \%$ dengan kategori baik, 3 orang atau 10,71\% dengan kategori cukup, 2 orang atau $7,14 \%$ dengan kategori kurang dan 3 orang atau $10,71 \%$ dengan kategori sangat kurang. Persentase ketuntasan belajar siswa disajikan pada Tabel 5 .
Tabel 4

Data Distribusi Frekuensi Nilai Tes Siklus I

\begin{tabular}{|c|c|c|c|}
\hline $\begin{array}{l}\text { Persentase } \\
\text { Skor Yang } \\
\text { Diperoleh }\end{array}$ & Kategori & $\begin{array}{l}\text { Jumlah } \\
\text { Siswa }\end{array}$ & Persentase \\
\hline $90-100$ & $\begin{array}{l}\text { Sangat } \\
\text { Baik }\end{array}$ & 8 & $28,58 \%$ \\
\hline $80-89$ & Baik & 12 & $42,86 \%$ \\
\hline $75-79$ & Cukup & 3 & $10,71 \%$ \\
\hline $65-74$ & Kurang & 2 & $7,14 \%$ \\
\hline $0-64$ & $\begin{array}{l}\text { Sangat } \\
\text { Kurang }\end{array}$ & 3 & $10,71 \%$ \\
\hline Jumlah & & 28 & $100 \%$ \\
\hline $\begin{array}{l}\text { Sumber: } \\
\text { Siklus I Per } \\
2015\end{array}$ & $\begin{array}{l}\text { Data Analis } \\
\text { nelitian Tind }\end{array}$ & $\begin{array}{l}\text { sis Nilai Te } \\
\text { dakan Kelas }\end{array}$ & $\begin{array}{l}\text { eori Tes } \\
\text { s Tahun }\end{array}$ \\
\hline \multicolumn{4}{|c|}{ Tabel 5} \\
\hline \multicolumn{4}{|c|}{$\begin{array}{c}\text { Data Distribusi Frekuensi Ketuntasan } \\
\text { Belajar Siswa pada Tes Siklus I }\end{array}$} \\
\hline Skor $\quad F$ & rekuensi $\mathrm{F}$ & $\begin{array}{c}\text { Persentase } \\
(\%)\end{array}$ & Kategori \\
\hline $100-75$ & 23 & $82,15 \%$ & Tuntas \\
\hline $74-100$ & 5 & $17,85 \%$ & $\begin{array}{l}\text { Tidak } \\
\text { Tuntas }\end{array}$ \\
\hline Jumlah & 28 & 100 & \\
\hline
\end{tabular}

Hasil distribusi frekuensi ketuntasan hasil belajar siswa pada tes siklus I diperoleh bahwa dari 28 siswa kelas X SMK Negeri 2 Pinrang terdapat 23 orang atau $82,15 \%$ yang mencapai batas lulus atau sudah kompeten. Hasil juga memperlihatkan masih terdapat 5 siswa atau $17,85 \%$ yang belum mencapai batas kelulusan atau belum kompeten berdasarkan kriteria ketuntasan minimal (KKM) dalam kurikulum satuan tingkat pendidikan (KTSP) serta tuntutan sekolah yakni 
minimal $85 \%$, maka dengan demikian perlu dilakukannya penelitian berlanjut pada siklus berikutnya

\section{Hasil Penelitian Siklus II}

\section{a. Hasil Tes Siklus II}

Perbaikan dilakukan sesuai hasil refleksi pada siklus II. Hasil belajar siswa pada mata pelajaran proses pengolahan dan pengawetan dengan menggunakan metode discovery disajikan pada Tabel 6.

\begin{tabular}{|c|c|c|c|}
\hline \multicolumn{4}{|c|}{$\begin{array}{c}\text { Tabel } 6 \\
\text { Data Distribusi Frekuensi Nilai Tes } \\
\text { Siklus II }\end{array}$} \\
\hline $\begin{array}{l}\text { Persentase } \\
\text { Skor Yang } \\
\text { Diperoleh }\end{array}$ & Kategori & $\begin{array}{l}\text { Jumlah } \\
\text { Siswa }\end{array}$ & Persentase \\
\hline 90-100 & $\begin{array}{c}\text { Sangat } \\
\text { Baik }\end{array}$ & 14 & $50 \%$ \\
\hline $80-89$ & Baik & 9 & $32,14 \%$ \\
\hline $75-79$ & Cukup & 4 & $14,29 \%$ \\
\hline $65-74$ & Kurang & 0 & 0 \\
\hline $0-64$ & $\begin{array}{l}\text { Sangat } \\
\text { Kurang }\end{array}$ & 1 & $3,57 \%$ \\
\hline Jumlah & & 28 & $100 \%$ \\
\hline
\end{tabular}

Sumber : Data Analisis Nilai Teori Tes Siklus II Penelitian Tindakan kelas Tahun 2015

Hasil penelitian diperoleh menunjukkan bahwa dari 28 siswa kelas X SMK Negeri 2 Pinrang terdapat 14 orang atau $50 \%$ dengan kategori sangat baik, 9 orang atau $32,14 \%$ dengan kategori baik, 4 orang atau 14,29\% dengan kategori cukup, kategori kurang tidak ada dan 1 orang atau 3,57\% dengan kategori sangat kurang. Persentase ketuntasan belajar siswa dapat dilihat pada Tabel 7 .
Tabel 7

Distribusi Frekuensi Ketuntasan

Belajar Siswa pada Tes Siklus II

Skor Frekuensi Persentase Kategori $(\%)$

\begin{tabular}{cccc}
\hline $100-75$ & 27 & $96,43 \%$ & $\begin{array}{c}\text { Tuntas } \\
\text { Tidak }\end{array}$ \\
$74-100$ & 1 & $3,57 \%$ & \begin{tabular}{c} 
Tuntas \\
\hline Jumlah
\end{tabular} \\
\hline
\end{tabular}

Hasil tes siklus II diperoleh bahwa dari 28 siswa kelas X SMK Negeri 2 Pinrang sudah $96,43 \%$ yang telah mencapai batas lulus. Hasil dari daftar frekuensi dapat disimpulkan bahwa secara klasikal siswa sudah bisa dikatakan berkompeten, karena sebanyak 27 Siswa atau 96,43\% yang memperoleh hasil nilai pada siklus $\| \geq 75$ atau di atas penetapan kriteria ketuntasan minimal yang terdapat dalam kurikulum Tingkat Satuan Pendidikan (KTSP) pada lembaga SMK Negeri 2 Pinrang.

\section{B. Pembahasan Hasil Penelitian}

\section{a. Penilaian Hasil Belajar Teori}

Sebelum penerapan metode discovery, hasil tes awal nampak bahwa masih ada siswa yang belum lulus atau belum berkompeten pada mata pelajaran proses pengolahan dan pengawetan dimana tingkat pencapaian prestasinya hanya $46,43 \%$ dan tidak memenuhi syarat berdasarkan tuntutan sekolah yakni $85 \%$. Rincian penilaian yakni, ada 1 siswa atau 3,57\% yang termasuk dalam kategori sangat baik, 7 siswa atau $25 \%$ yang termasuk baik, 5 siswa atau $17,86 \%$ yang termasuk kategori kurang dan ada 9 siswa atau $32,14 \%$ yang termasuk dalam kategori sangat kurang. Berdasarkan data frekuensi tersebut maka dapat dikatakan secara klasikal 
bahwa siswa yang lulus atau yang berkompeten di kelas X SMK Negeri 2 Pinrang ada 13 orang atau $46,43 \%$, sedangkan yang belum lulus atau belum berkompeten ada 15 orang atau $53,57 \%$. Setelah metode discovery diterapkan pada siklus | dan siklus || dengan jumlah rata-rata persentase secara akumulatif, terjadi perubahan pada hasil belajar yang dapat menunjang prestasi siswa. Data jumlah persentase secara akumulatifnya yaitu $89,29 \%$ dengan distribusi frekuensi 39,29\% yang termasuk dalam kategori sangat baik, $37,5 \%$ yang termasuk baik, $12,5 \%$ yang termasuk kategori cukup, 3,57\% yang termasuk dalam kategori kurang dan $7,14 \%$ yang termasuk dalam kategori sangat kurang. Berdasarkan data frekuensi yang dijumlah secara akumulatif data nilai siklus I dan siklus II tersebut maka dapat dikatakan bahwa prestasi belajar siswa sudah mencapai syarat ketentuan berdasarkan tuntuan sekolah yakni $89,29 \%$.

\section{b. Penilaian Hasil Belajar Praktikum}

Nilai yang diperoleh siswa dari hasil praktikum pada siklus I dan siklus II dengan jumlah rata-rata persentase diakumulasikan secara klasikal yakni frekuensi dengan kategori sangat baik sebanyak $42,85 \%$, yang termasuk baik $35,71 \%$, yang termasuk kategori cukup ada $12,50 \%$, yang termasuk dalam kategori kurang ada $5,35 \%$ dan yang termasuk dalam kategori sangat kurang ada $3,57 \%$. Hasil daftar frekuensi tersebut dapat dikatakan secara klasikal bahwa persentase siswa yang berkompeten berjumlah $91,06 \%$, dan yang belum lulus pada praktikum tersebut berjumlah $8,92 \%$. Perolehan persentase tersebut sudah memenuhi standar nilai praktikum $\geq 75$ berdasarkan kriteria ketuntasan minimal dan telah memenuhi syarat dalam pencapaian prestasi belajar siswa $\geq 85 \%$.

\section{KESIMPULAN DAN SARAN}

\section{A. Kesimpulan}

Berdasarkan hasil penelitian dapat disimpulkan bahwa setelah penerapan metode discovery pada mata pelajaran proses pengolahan dan pengawetan siswa kelas X SMK Negeri 2 Pinrang terjadi peningkatan prestasi belajar siswa, hal ini dapat dilihat dari peningkatan nilai rata-rata yang diperoleh siswa yang mengerti selama penelitian ini berlangsung.

\section{B. Saran}

Sesuai dengan kesimpulan yang diperoleh dari penelitian ini, disarankan:

1. Kepada kepala satuan pendidikan sebagai pengambil kebijakan agar menghimbau kepada guru bidang keahlian lain untuk menerapkan dan mengembangkan metode beberapa metode pengajaran termasuk metode discovery.

2. Untuk materi praktikum, sebaiknya guru menggunakan metode yang mengarahkan siswa langsung mengenal pada pekerjaannya sehingga hasil pelajaran yang diperoleh dapat meningkat, seperti penggunaan metode discovery pada mata pelajaran proses pengolaha dan pengawetan.

3. Kepada siswa supaya lebih meningkatkan prestasi dalam mengikuti mata pelajaran khusunya yang menggunakan beberapa penerapan metode termasuk metode discovery yang digunakan oleh guru pada mata pelajaran lain. 
DAFTAR PUSTAKA

Abdul Haling, 2007. Belajar Dan Pembelajaran. Makassar : Badan Penerbit UNM. Makassar

Lestari. 2004. Teknik Penilaian. Jakarta: Departemen Pendidikan Nasional

Roestiyah N.K. 2001. Strategi Belajar Mengajar. Jakarta: PT. Bumi Aksara

Sugiyono. 2008. Metode penelitian Kuantitatifdan Kualitatif. Bandung: Alfabeta

Sunarto. 2012. Pengertian prestasi belajar. Fasilitatoridola(online). (http://sunartombs. wordpress.com/2009/01/05/penger tian-prestasibelajar/).diakses pada tanggal 25 Mei 2015.

Syaiful Bahri Djamarah dan Aswan Zain. 2006. Strategi Belajar Mengajar. Jakarta: Rineka Cipta.

W.S Winkel. 2014. Psikologi Pengajaran (Email:sketsabook@gmail.com).Yo gyakara: Sketsa 